\title{
The Florida Citrus Industry: Government and Non-Government Organizations ${ }^{1}$
}

\author{
Thomas H. Spreen, Ronald P. Muraro, Fritz M. Roka, and R. Allen Morris ${ }^{2}$
}

The Florida citrus industry has a long history of cooperation both among competing firms and between firms and government entities. The purpose of this document is to identify the major organizations that work for the benefit of the Florida citrus industry and to provide a brief introduction to their activities. For the purposes of this document, these groups are classified as:

- Government entities

- Industry research panels

- Voluntary trade organizations

- Other organizations

FE812 is one of five documents in the $A$ Glossary for the Florida Citrus Grower series. Other documents in this series can be accessed online at http://edis.ifas.ufl.edu.

\section{Government Entities}

\section{Florida Citrus Commission, Florida Department of Citrus}

The Florida Citrus Commission and the Florida Department of Citrus were formed in 1935. The Florida Citrus Commission (Commission) is a 12-member board appointed by the Governor to oversee the Florida Department of Citrus (FDOC). The FDOC provides marketing, research, and regulatory support for Florida citrus products. Although it is a state agency, the FDOC operates under a state marketing order which established a means to raise revenue through a tax. Growers fund the FDOC through an excise tax placed on each box of citrus that moves through processing plants and fresh fruit packinghouses. The Commission sets the tax rate each year. Historically, about 80 percent of the FDOC operating budget ( $\$ 62$ million in 2008-2009) is allocated to marketing. With the onset of HLB (huanglongbing, or citrus greening disease) in Florida, the Commission has directed 16

1. This is EDIS document FE812, a publication of the Food and Resource Economics Department, Florida Cooperative Extension Service, Institute of Food and Agricultural Sciences, University of Florida, Gainesville, FL. Published October 2009. Please visit the EDIS website at http://edis.ifas.ufl.edu.

2. Thomas H. Spreen, professor, Food and Resource Economics Department, University of Florida, Gainesville, FL; Ronald P. Muraro, professor and extension economist, Food and Resource Economics Department, University of Florida, Citrus Research and Education Center, Lake Alfred, FL: Fritz M. Roka, associate professor and extension economist, Food and Resource Economics Department, University of Florida, Southwest Florida Research and Education Center, Immokalee, FL; and R. Allen Morris, assistant extension scientist, Food and Resource Economics Department, University of Florida, Citrus Research and Education Center, Lake Alfred, FL, Food and Resource Economics Department, Florida Cooperative Extension Service, Institute of Food and Agricultural Sciences, University of Florida, Gainesville, FL.

The Institute of Food and Agricultural Sciences (IFAS) is an Equal Opportunity Institution authorized to provide research, educational information and other services only to individuals and institutions that function with non-discrimination with respect to race, creed, color, religion, age, disability, sex, sexual orientation, marital status, national origin, political opinions or affiliations. U.S. Department of Agriculture, Cooperative Extension Service, University of Florida, IFAS, Florida A. \& M. University Cooperative Extension Program, and Boards of County Commissioners Cooperating. Millie FerrerChancy, Interim Dean 
percent of the FDOC's budget to disease research.

The research money is channeled through the Florida Citrus Production Research Advisory Council (FCPRAC) (see below) for disbursement to researchers in the form of competitive grants. For more information on the FDOC go online to http://www.fdocgrower.com.

The Commission also has various advisory committees to guide policy on issues. These groups include:

- Brix Acid Unit Advisory Committee

- Citrus Harvesting Research Advisory Council

- Citrus Statistics Advisory Council

\section{Florida Citrus Production Research Advisory Council (FCPRAC)}

The Florida Citrus Production Research Advisory Council (FCPRAC) has operated since 1991 under the Florida Citrus Production Research Marketing Order. The order allows growers to tax themselves up to one cent per box of citrus and to direct those funds solely to research. FCPRAC's board, which consists of 14 grower representatives serving four-year terms, selects among competing research proposals and awards grants to selected proposals. The FCPRAC board determines the tax rate annually. The tax is collected by the Florida Department of Agriculture and Consumer Services (FDACS) and historically raises around $\$ 1.5$ million annually for research projects. Faced with the urgency of HLB and related research, the Florida Legislature and the Florida Department of Citrus (FDOC) contributed an additional $\$ 12$ million to FCPRAC for distribution during the 2008-2009 season. The additional money funded more than 100 research projects. For more information go online to http://www.fcprac.com.

\section{Citrus Administrative Committee (CAC)}

The Citrus Administrative Committee (CAC) is authorized by Federal Marketing Order 905 to determine the grade, size, maturity, quality, and volume regulations of fresh Florida citrus. The order was promulgated in 1939 and was last amended under formal rulemaking on September 8, 1989. The CAC is made up of 18 members and their alternates. Nine members and alternates are growers; eight members and alternates are shippers; and one member and alternate represent the public. All members serve one-year terms of office that run from August 1st through July 31 st. Members may serve a maximum of three consecutive terms. More information about the CAC can found online at http://www.citrusadministrativecommittee.org/.

\section{Institute of Food and Agricultural Sciences at the University of Florida}

The Institute of Food and Agricultural Sciences at the University of Florida (UF/IFAS) conducts research, extension, and education programs on citrus through its main campus in Gainesville and at three research and education centers located at Lake Alfred, Immokalee, and Fort Pierce. In addition, a network of multi-county Extension faculty is located in various county offices throughout the citrus production region. UF/IFAS is funded by state appropriations from the Florida Legislature through the USDA formula funding, and by grants and contracts from a wide range of public and private agencies.

The Citrus Research and Education Center (CREC) in Lake Alfred was established in 1917 with grower funds and is the oldest and largest off-campus research center in the UF/IFAS organization. CREC is unique among research centers in that it focuses entirely on one commodity, citrus; is the largest citrus research facility in the world; and has the world's largest citrus library.

Today, faculty members work to provide relevant and timely assistance through the development and delivery of information, technology, and educational opportunities to numerous and diverse clients. University of Florida students pursuing master's degrees and doctorates in agricultural fields may enroll in several courses at CREC or attend via a long-distance video conferencing network. Designated Extension faculty members serve the public by providing publications and conducting educational programs for growers, processors, packers, related industry groups, and homeowners. Short courses, field demonstrations, and seminars also are held at CREC. 
Eight disciplinary departments of the University of Florida are represented at CREC, including horticultural sciences, soil and water science, plant pathology, entomology and nematology, microbiology and cell science, agricultural and biological engineering, food science and human nutrition, and food and resource economics. Faculty are organized into interdisciplinary working groups and address a wide array of topics.

In addition, CREC is home to the scientific research staff of the Florida Department of Citrus (FDOC). For more information go online to http://www.crec.ifas.ufl.edu.

\section{Agricultural Research Service, United States Department of Agriculture}

The United States Department of Agriculture, Agricultural Research Service (USDA/ARS) has a facility located at Fort Pierce. The USDA/ARS unit has been a major player in research related to both citrus canker and citrus greening. It is formally known as the U.S. Horticultural Research Laboratory (USHRL), with national responsibility for control methods for insect pests of citrus and other subtropical fruits, vegetables, and ornamentals; for basic physiological, biochemical, and pathological research on postharvest problems of horticultural crops; and for developing new citrus scion and rootstock varieties that enhance fruit quality and yield and are resistant to disease. There are 20 Ph.D. research scientists divided into three units: horticulture and breeding, subtropical insects, and subtropical plant pathology (our thanks to Dr. Calvin Arnold for supplying this information).

\section{Florida Agricultural Statistics Service}

The Florida Agricultural Statistics Service (FASS) is a joint effort of the United States Department of Agriculture, National Agricultural Statistics Service (USDA/NASS) and the Florida Department of Agriculture and Consumer Services (FDACS). It is located in Orlando and collects data on a wide array of crops and livestock products produced in Florida, including citrus. The Citrus Summary is published annually and reports production, utilization, and prices for all major citrus varieties produced in Florida, as well as data on citrus produced in other U.S. states. FASS also publishes bi-annually the Commercial Citrus Tree Inventory, another valuable report that provides tree numbers and acreage by age, variety, and county. For more information go online at http://www.nass.usda.gov/fl.

\section{Industry Research Panels}

\section{Citrus Research and Development Foundation, Incorporated}

The Citrus Research and Development Foundation (Foundation) was created in May 2009. The Foundation exists as a Florida not-for-profit corporation, is organized as a Direct Support Organization (DSO), and is certified by the University of Florida's Board of Trustees. It operates for the benefit of the citrus industry and the state of Florida, in a manner consistent with the goals of the University of Florida. The Foundation plans to serve as ground zero for Florida citrus research by coordinating citrus disease researchers, managing contracts, assessing research progress, and addressing intellectual property and other commercialization and product development issues. Ten of the Foundation's board members are citrus growers and three represent the University of Florida.

\section{The Florida Citrus Industry Research Coordinating Council (FCIRCC)}

The Florida Citrus Industry Research Coordinating Council (FCIRCC) was established in 2001 through the cooperation of many Florida citrus industry organizations. FCIRCC was created to assure that the most pressing research needs facing the citrus industry were addressed in an efficient manner. Through a numerical ranking system, the FCIRCC annually establishes research priorities based on input from all segments of the industry. Priority areas that lack adequate resources are identified as gaps and documented for further investigation. A final review with interested parties representing Florida citrus growers will identify the research gaps and the resources needed to bridge these gaps. Membership on the FCIRCC is divided between various industry organizations. In addition to the main council, the FCIRCC has established two active task forces to discuss progress on canker and 
HLB research, respectively. For more information go online to http://www.fcircc.org.

\section{Florida Foundation Seed Producers, Incorporated}

The Florida Foundation Seed Producers, Inc. (FFSP) is a not-for-profit corporation acting on behalf of the Florida Agricultural Experiment Station for the release of proprietary UF germplasm. For more information go online to http://ffsp.net/.

\section{New Varieties Development and Management Corporation}

The New Varieties Development and Management Corporation (NVDMC) is a not-for-profit organization funded by Florida citrus growers through the Florida Citrus Commission. Its stated mission is to "provide Florida growers affordable and timely access to new citrus varieties that will enhance Florida's competitive position and enhance the potential of intrastate, domestic, and international breeding programs, while maximizing the crop values of the growers and packers it serves." About 70 percent of the NVDMC's budget goes directly to breeding programs.

\section{Voluntary Trade Organizations}

\section{Florida Citrus Mutual}

Formed in 1948, The Florida Citrus Mutual (FCM) serves as the lobbying voice for Florida citrus growers in Washington, D.C. and Tallahassee, Florida. The group, which maintains about 8,000 grower members, also provides market information, communications, and grower affairs to its membership. Led by a board of 21 member-elected directors from various growing regions across the state, FCM's annual budget is about $\$ 3$ million, which is generated through a per-box assessment. For more information go online to http://www.flcitrusmutual.com.

\section{Regional Grower Associations}

Formed at various times over the past three decades, four regional grower associations each handle local issues for their members, such as water management, community relations, and local planning. Politically active growers in each growing region established the associations after rapid urban development in Florida began conflicting with citrus farming, which created the need for more local representation for the industry. The regional associations subsist on small budgets funded by annual membership fees. Often, the larger citrus organizations use the regional associations as sounding boards for issues or ideas circulating around the industry. The regional associations are as follows:

- Gulf Citrus Growers Association (http://www.gulfcitrus.org/)

- Highlands County Citrus Growers Association (http://www.hccga.com/)

- Indian River Citrus League (http://www.ircitrusleague.org/)

- Peace River Valley Citrus Growers Association (http://www.prvcitrus.org/)

\section{Florida Citrus Packers}

Chartered in 1960, the Florida Citrus Packers is a non-profit cooperative association representing growers whose focus is selling their citrus to the fresh market rather than to processors. Fresh growers face unique shipping issues that processed growers do not often face. Florida Citrus Packers is supported by a per-box assessment on all fresh citrus shipments from member companies. Representing approximately 90 percent of the volume of all fresh shipments from Florida each year, the organization endeavors to solve the shipping problems its members encounter and to secure cooperation between producers and shippers in the marketing of fresh citrus.

\section{Florida Citrus Processors Association}

Established in 1938, the Florida Citrus Processors Association (FCPA) represents companies that process citrus fruit into juice, including U.S.-based companies (e.g., Tropicana, Minute Maid, and Florida's Natural) and Brazilian-based companies (Cutrale, and Citrosuco). The FCPA's stated mission is to represent, communicate, protect, and enhance the interests of its members and to promote the growth and welfare of 
the citrus industry. For more information go online to http://www.fcplanet.org.

\section{Florida Citrus Production Managers Association}

The Florida Citrus Production Managers Association (FCPMA) is made up of Florida citrus production managers, the people who coordinate all aspects of citrus growing for fruit companies. FCPMA meets quarterly and serves as an educational clearinghouse for production managers through seminars with educators, researchers, and extension agents.

\section{Florida Nursery, Growers, and Landscape Association, Citrus Nursery Division}

The Citrus Nursery Division of the Florida Nursery, Growers, and Landscape Association (FNGLA) was originally formed in 1958 as the Florida Citrus Nurserymen's Association (FCNA) to promote the agricultural interests of citrus nurseries as well as to encourage and facilitate the efficient production, distribution, and sale of citrus nursery stock and related products. The organization serves as a voice for citrus nurseries to elected officials and regulators. In addition, the Citrus Nursery Division has established a code of ethical practices to guide citrus nurseries in their business. The FCNA became a section of the larger Florida Nursery, Growers, and Landscape Association in 2006. For more information go online to http://www.fngla.org/divisions/citrus.asp.

\section{Other Organizations}

\section{Florida Fruit and Vegetable Association}

The Florida Fruit and Vegetable Association (FFVA) is a non-profit agricultural trade organization whose mission is to enhance the business and competitive environment for producing and marketing fruits, vegetables and other crops.

FFVA members have access to a team of experts on crop protection, labor, water management, government relations, marketing and communication. The FFVA offers several membership categories: producer members, affiliate members, trade associate members and insurance associate members (companies affiliated with FFVA Mutual Insurance Co.).

FFVA manages and/or owns three subsidiary companies:

1. Florida East Coast Travel Service - recruits, provides travel, and supports labor through the $\mathrm{H}-2 \mathrm{~A}$ and $\mathrm{H}-2 \mathrm{~B}$ programs of the U.S. Department of Labor and the U.S. Citizenship and Immigration Services

2. Third Party Registrations, Incorporated administers 24(c) limited liability pesticide registrations for FFVA members

\section{FFVA Mutual Insurance Company -} provides workers' compensation insurance for numerous industry sectors, including agriculture, in the Southeast

FFVA was organized from the vegetable committee of the Florida Farm Bureau in 1941. Known initially as the Florida Vegetable Committee, the organization's primary focus was to represent vegetable growers during wartime regulation of production quotas, rationing, labor availability, and transportation. Formally incorporated as a state organization in 1943, FFVA has become an important voice of agriculture in Florida.

\section{Florida Farm Bureau}

The Florida Farm Bureau is the largest farm organization in Florida and represents a wide array of commodity interests. Based in Gainesville, the Florida Farm Bureau works on behalf of its members in the legislative arena on matters related to state and federal government policies that affect Florida agriculture. It is also the parent of Farm Bureau Insurance, a major casualty insurer. 